\title{
Fall of ethanol
}

Environ. Hist. emy056 (2018)

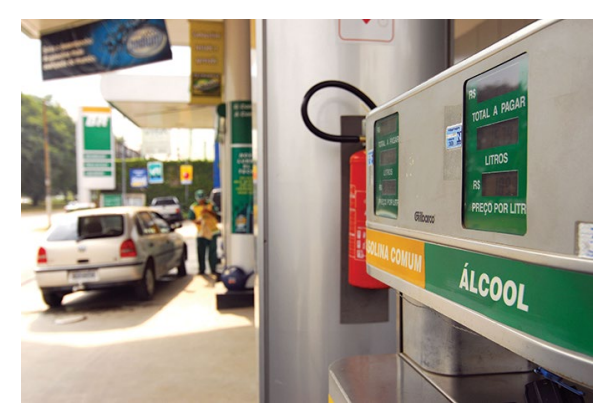

Credit: Bloomberg / Contributor

After the oil shocks of the 1970s, Brazil's military government instituted a programme of ethanol production called Proálcool designed to replace petroleum use in automobiles, along with the manufacture of millions of cars to run on ethanol. The programme involved extensive government policies and market incentives to shift Brazil's sugar industry towards ethanol for domestic consumption, but ended in 1990 after enormous economic shocks.

However, according to Jennifer Eaglin at the Ohio State University, the demise of Proálcool was also a function of unprecedented droughts in the sugarproducing regions of Brazil beginning in 1985-1986. After sugar and ethanol production had doubled in the previous decade to meet newfound demand caused by $95 \%$ of new Brazilian cars running on ethanol, the drought reduced ethanol production at the same time that petroleum prices decreased (meaning that ethanol was no longer price competitive) and sugar prices soared on the world market, leading producers to switch away from making ethanol. State oil companies used up their reserves and the government tried subsidies, but public faith in ethanol as a stable fuel supply eroded and led to a democratically elected president ending the ethanol-only policy.

Ryan Scarrow

Published online: 15 October 2018

https://doi.org/10.1038/s41893-018-0162-5 